\title{
A study on the salinization of coastal water of Sidi Boughaba Lake (Ramsar site 1980) in Morocco using the characteristic reports
}

\author{
Mohamed Najy ${ }^{1, *}$, Mohamed Lachhab ${ }^{1}$, Hassan Ech-chafay ${ }^{1}$, Fatima Zahra Talbi $^{2}$, Abderrahman Achhar ${ }^{3}$, and Driss \\ Belghyti $^{1}$ \\ ${ }^{1}$ Laboratory of Agro-physiology, Biotechnology, Environment and Quality, Department of Biology Ibn Tofail University, Faculty of \\ Science Kenitra, Morocco \\ ${ }^{2}$ Laboratory of biochemistry, neurosciences, natural resources and the environment. Faculty of Sciences and Technologies, BP 577, Hassan \\ First University, Settat, Morocco \\ ${ }^{3}$ Laboratory of renewable energy and Environment Department of physics Ibn Tofail University, Faculty of Science Kenitra, Morocco
}

\begin{abstract}
The Lake Sidi Boughaba is a Ramsar site (1980) located on the Atlantic coast of north-west Morocco. It is oriented NNE - SSW and located in a secondary interdunal depression formed in a complex of the main wetlands of Morocco. The waters of this lake are deteriorating in quality, with increasing salinization. To identify the processes and chemical reactions that govern salinization, the main major elements as well as the $\mathrm{pH}$, electrical conductivity and salinity were monitored during the winter and summer seasons of the years, 2016-2017 in 6 sites distributed throughout the year. The interpretation of the analysis data is carried out using the correlation of the major elements with the chlorides, the Piper diagram and the variation of the ionic ratios $\mathrm{Na} / \mathrm{Cl}, \mathrm{SO} 4 / \mathrm{Cl}, \mathrm{Mg} / \mathrm{Ca}$ and the calculation of the saturation index. The saturation index is calculated by the software PHREEQC 2.8 , used for modelling the state of saturation of minerals. The results of these analyzes revealed a variety of origins and processes of salinization of the waters. The hydro chemical study shows that the waters are brackish too salty; they are characterized by sodium chloride facies. This remarkable transition is mainly due to the intense evaporation that accentuates the mineralization. The values of the saturation index of the chemical minerals show the under saturation the anhydrite of the gypsum and the halite, on the other hand, the saturation or even supersaturation by the calcite and dolomite. The characteristic ratios of the chemical composition of waters show that salinity has two main origins: ion exchange between rock-water and marine influence by aerosols and sea spray.
\end{abstract}

\section{Introduction}

This Salinization of waters is one of the main causes of water quality degradation in the world. The mechanisms responsible for the salinity of a hydrological system are diverse and complex. Thus the mode of salinization depends on the geological and climatic context [1]. The principal vectors involved in the salinization of water masses are marine intrusion, mixing with ancient brines, dissolution of evaporitic formations [2], [3], but also various anthropogenic sources. [1], [4], [5].

The surface and underground waters, initially weakly mineralized, can, by interaction with the rocks of the watershed and by successive evaporation, become saline. The salt concentrations can increase until the precipitation of evaporites [6]. The salinity of the waters is one of the major problems in Morocco, given its devastating effect on water quality. It is often related to the dissolution of geological formations, the effect of evaporation and the effect of marine intrusion [7]-[14].

The Lake Sidi Boughaba is one of the wetlands of the north-west coast of Morocco, which is a migratory stopover, a winter refuge and a breeding site for several bird species. This ornithological interest earned this site to be classified as RAMSAR site in 1980. Its water varies between brackish and brine with a salinity ranging from 3 to 6 grams per liter depending on the season. The lake has no communication with the ocean and its waters do not seem to be in contact with the saline groundwater [15], [16].

The objective of this study is to determine the spatial extension of this salinization and to be able to define its origin. For this, we have used chemical indicators, namely the major elements to determine the different facies of water that can indicate the different processes responsible for the phenomenon of salinization [17].

\section{Materials and methods of study}

\subsection{Study area}

The Lake Sidi Boughaba is located on the Atlantic coast of the North-West of Morocco (figure 1), directed - SSW

\footnotetext{
*Corresponding author: Mohamed.najy@uit.ac.ma
} 
and located in a depression internal. It extends on $5,5 \mathrm{~km}$ length and a variable width from 100 to 350 meters and a depth varying between 0,5 and 2,50 meters maximum. The existence of this water mass is because the topographic surface is located on a coast lower than the piezometric surface of the coastal groundwater, rainwater, and streaming [16]. Whose maximum water level is at the end of the winter (March) and minimum right before the return of the rains (September). Because of the great variation of the level (nearly $1 \mathrm{~m}$ ), only part of this lake, of which the depth is sufficient, remains in water all the year (either much less than half of the surface)[18].

The climate of the region is Mediterranean and semiarid. Based on climatological data provided by the Kenitra Meteorological Service, average temperatures are $13{ }^{\circ} \mathrm{C}$ in winter and $27^{\circ} \mathrm{C}$ in summer [18]

\subsection{Geological data}

The geological formations of the coastline of the Maâmora zone (Fig. 2) consist mainly of sandstone and quaternary sands or dunes. These formations differ from the Plio-Villafranchian formations and are surmounted by red silts more or less sandy and cover the ground in this coastal area up to 3 or $4 \mathrm{~km}$. The conglomerate red beds are between 33 and $48 \mathrm{~m}$ deep, ie -24 to $-43 \mathrm{~m}$ above sea level [15].

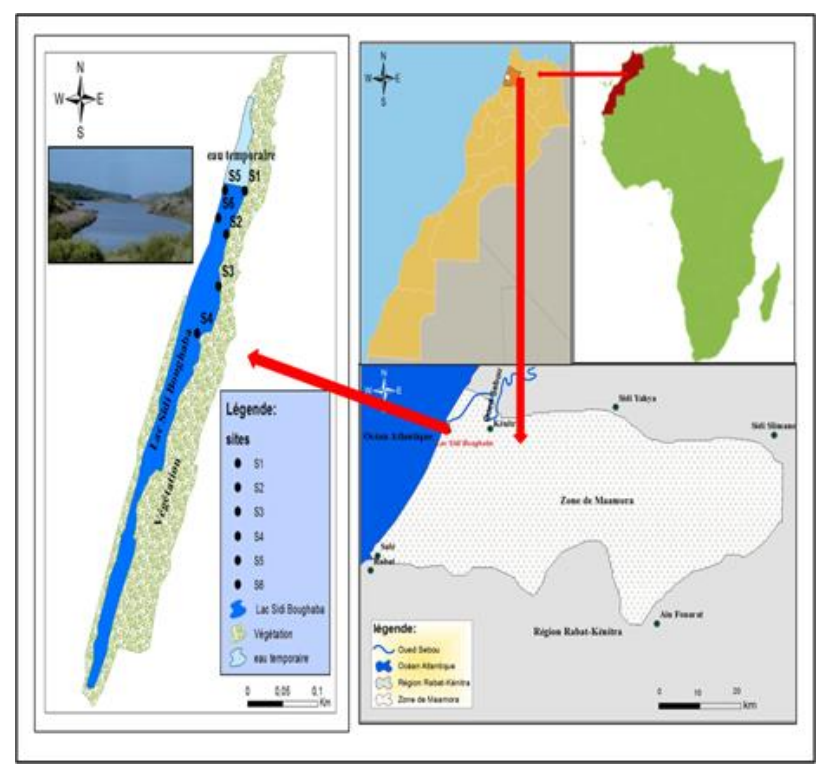

Fig.1. Geographical Situation of the study area

\subsection{Hydrology}

Some small streams cross the Maamora in the same direction, from SSW to NNE; their small size is due to the limited area of watersheds and low runoff on sandy, vegetated soils. Only the Tiflet river, a $560 \mathrm{~km}^{2}$ watershed, is sustainable and its average annual flow is around $0,7 \mathrm{~m}^{3} / \mathrm{s}$. In total, river discharge each year the equivalent of $4 \%$ of rainfall representing the sum of runoff and drainage in the water table. Also, there are many days (temporary pools), whose cumulative area is of the order of $10 \mathrm{~km}^{2}$ and which evaporates about $2 \%$ of the rainfall.

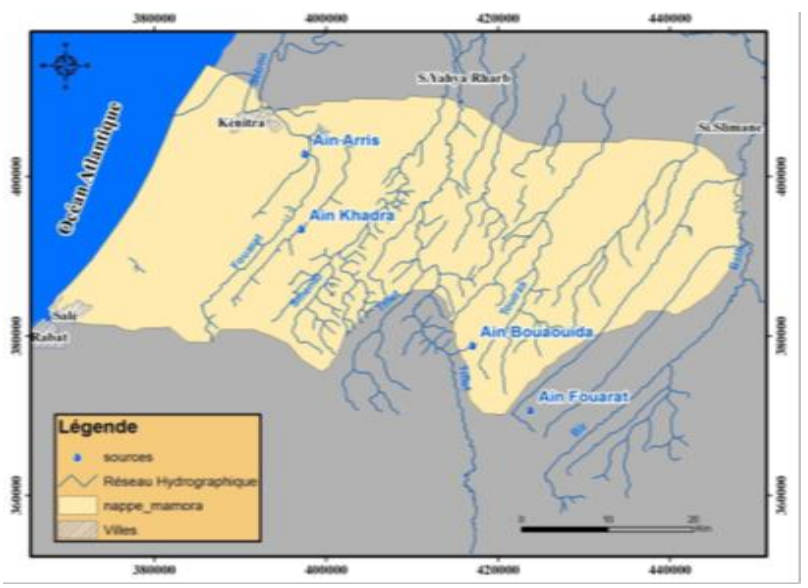

Fig. 2. Hydrographic map of the Maâmora plateau [20]

\subsection{Hydrologeology}

The sandstone and stony formations of the pliovillafranchien harbor a water table, the substratum of which consists of the thick miocene clay series. This water table flows towards the east (180 km2 basin), towards the ocean $\left(390 \mathrm{~km}^{2}\right)$ and towards the Gharb plain $\left(1550 \mathrm{~km}^{2}\right)$ where it feeds the deep aquifer.

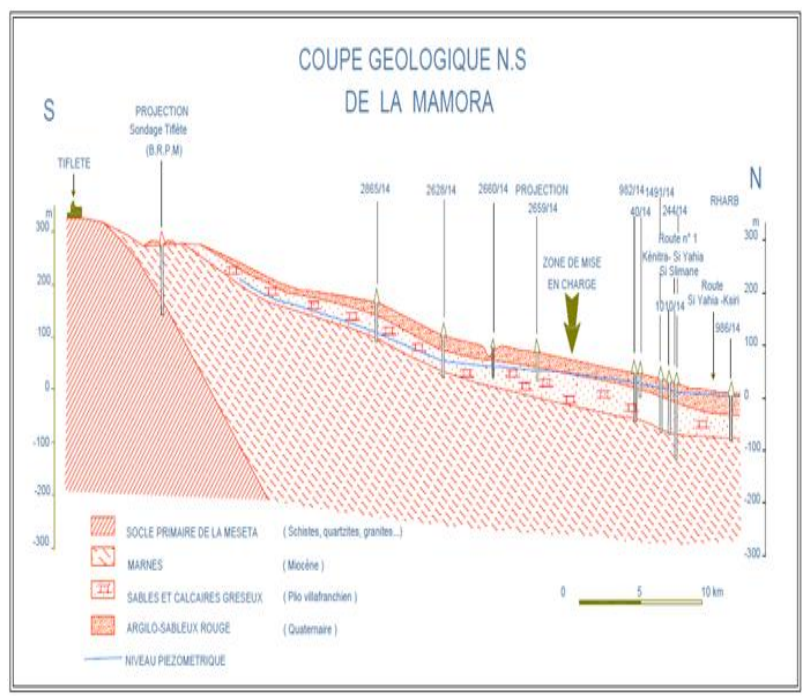

Fig. 3. Cut of the depths of the water table of Maâmora

The aquifer is generally 10 to 30 meters thick and usually between 20 and 40 meters deep, but up to 80 meters deep; its average permeability is $3 \cdot 10^{-4} \mathrm{~m} / \mathrm{s}$, its transmissivity of $1.10^{-2} \mathrm{~m}^{2} / \mathrm{s}$ and its storage coefficient between $1 \cdot 10^{-3}$ and $3,5 \cdot 10^{-2}$. Based on these data and detailed maps of the aquifer, the reserves are estimated at $300.10^{6} \mathrm{~m}^{3}$, this measure is modest and can be explained by the fact that only $15 \%$ of the precipitation benefits the aquifer, because of intense evapotranspiration

Above this important groundwater often exist, in Maamora, of small perched tablecloths constituting itself above the red clay which slows down the infiltration: their level is usually close to the surface (1 to 3 meters) and they are identified by the few wells with hand which exploit them (suburbs of Kenitra in particular). Generally, these tablecloths are drained in the current of the summer. 


\subsection{Sampling and analysis}

Within the framework of this study, taking away are carried out on several sites distributed around the Lake Sidi Boughaba (. 1) The whole of sampling was the subject of physicochemical analyses. The chemical and physical parameters not preserved (temperature, $\mathrm{pH}$, electric conductivity and salinity) were measured on the ground at the time of the taking away. The chemical analyses $\left(\mathrm{Cl}-, \mathrm{HCO}_{3}{ }^{-}, \mathrm{SO}_{4}{ }^{2-}, \mathrm{NO}_{3}{ }^{-}, \mathrm{Ca}^{2+}, \mathrm{Mg}^{2+}, \mathrm{Na}^{+}\right.$, and $\mathrm{K}^{+}$) were carried out at the laboratory of Agrophysiologie, Biotechnology, environment, and Quality and in the Center of Analysis of the Faculty of Science.

The diagram of Piper was used to understand the chemistry of water of the Lake for the period of study (2016-2017): companion (August, September, and October) and companion (December, January, and February). Indices of saturation (IS) were calculated by using the program of modeling PHREEQC to study the influence of the interaction water-rock on the mineralization of water [21]. Since the study area is located in a region dominated by carbonate minerals and groundwater characterized by two main facies: calciumbicarbonates (Ca-Mg-CO3-HCO3) and sodium-chlorides (Na-K-Cl) [14]. Therefore, specific calculations have been made for carbonate minerals (dolomite, calcite, aragonite) and, also, for halite to understand the effect of salt sources on the water chemistry of Lac Sidi Boughaba. The minerals dissolution-precipitation processes were also analyzed using the characteristic ratios: $\mathrm{Na} / \mathrm{Cl}$, $\mathrm{Ca} / \mathrm{Mg}, \mathrm{HCO} 3 / \mathrm{Cl}, \mathrm{SO} 4 / \mathrm{Cl}, \mathrm{Ca} /(\mathrm{HCO} 3+\mathrm{SO} 4)$ [22]-[26].

\section{Results and discussion}

\subsection{Evolution of chemical elements}

The results of the chemical analysis of the waters are summarized in Table 1 . The $\mathrm{pH}$ values of the lake waters vary between a minimum of 7.05 and a maximum of 8.36 with an average of about 7.60. This indicates a very slight tendency towards a basic composition. The highest values were recorded in the wet period (wintering) and the lowest values were recorded in the dry period.

The electrical conductivity varies between $10440 \mu \mathrm{S}$ $/ \mathrm{cm}$ and $26000 \mu \mathrm{S} / \mathrm{cm}$, with an average of $18600 \mu \mathrm{S} / \mathrm{cm}$. This high salinity is determined by the high prevalence of $\mathrm{Cl}^{-}$and $\mathrm{Na}^{+}$ions, which correlate well with electrical conductivity $\left(\mathrm{r}=0.94\right.$ for $\mathrm{Cl}^{-}$and 0.98 for $\left.\mathrm{Na}^{+}\right)$. The evolution of the electrical conductivity in the lake's waters is visible at the season scale, where the high values are observed during the low-water period, while the lower values occur during the wintering period. This could be explained by a phenomenon of water dilution by increasing its volume during the rainy season.

The concentration of chlorides shows a large variation, with a minimum of $3790,64 \mathrm{mg} / \mathrm{l}$ and a maximum of $11990 \mathrm{mg} / \mathrm{l}$, the average is equal to 7401 , $51 \mathrm{mg} / \mathrm{l}$ and the very high standard deviation of 3052, 94 $\mathrm{mg} / \mathrm{l}$. It reflects a large variation in the chloride ion concentration of Lake Water.
Potassium ranges from 38,8 to $104,6 \mathrm{mg} / \mathrm{l}$, with an average of 70,3 mg/l. Calcium from 72,55 to $178,8 \mathrm{mg} / 1$. Magnesium concentrations show a wide variation, with a minimum of 83,52 and a maximum of $682,34 \mathrm{mg} / \mathrm{l}$, around an average of $402,45 \mathrm{mg} / \mathrm{l}$ and a high standard deviation of $257,28 \mathrm{mg} / \mathrm{l}$, which reflects a strong influence of high values.

It should be noted that the physicochemical characteristics of Lake water do not vary or a little from one site to another, but change with the seasons.

\subsection{Mechanisms of salt charge acquisition}

The study of the correlations between the concentrations of the principal major elements $\left(\mathrm{Cl}^{-}, \mathrm{Mg}^{2+}, \mathrm{Na}^{+}, \mathrm{K}^{+}, \mathrm{Ca} 2+\right.$ and $\mathrm{SO}_{4}^{2-}$ ) and the EC electrical conductivity which represents the total mineralization of the waters Table I, made it possible to go back to the origin of the mineralization of the waters of Lake Sidi Boughaba. The presence of a strong positive correlation between these ions and the total mineralization reflects the participation of these elements in the acquisition of the saline load of the waters and testifies to the presence of a common source of mineralization, which can only be explained by the dissolution of evaporites. Negative correlations are observed between $\mathrm{pH}$ and electrical conductivity, as well as between $\mathrm{pH}$ and ions that are most involved in mineralization $\left(\mathrm{Na}^{+}, \mathrm{Ca}^{2+}, \mathrm{Cl}^{-}, \mathrm{Mg}^{2+}, \mathrm{SO}_{4}{ }^{2-}\right.$ and $\left.\mathrm{K}^{+}\right)$. This can be explained by the fact that the waters with the highest salt content have a $\mathrm{pH}$ lower than the average $\mathrm{pH}$ of lake water (estimated at 7.6 on average for samples taken during the study period).

The knowledge of the saturation of water by some minerals allows saying in which chemical forms some elements are transported in the solutions. Calculation of the saturation index of calcite and Aragonite shows that the water collected is saturated or even supersaturated concerning these minerals during all the campaigns.

Also, the saturation index for halite and gypsum for all the samples vary respectively from -2.99 to -4.49 and from 1.61 to -1.98 ; which illustrates a saturation of the water concerning these minerals. This is explained by the effect of high values of the equilibrium constant of evaporite minerals $\mathrm{NaCl}$ (1.58); CaSO4 (- 4.85), which allows evaporitic elements to occur in water at high concentrations. On the other hand, for the carbonate minerals, the equilibrium constant is lower Dolomite ($17,02)$, Calcite $(-8,37)$, which produces rapid precipitation of the chemical elements.

\subsection{Chemical facies}

The representation of the major element concentrations of the waters of the region on the Piper diagram (Piper, 1944) shows that the chemical facies of the water evolve from the sodium chloride and sodium-potassium and sodium sulfate hydrofluoric facies $\mathrm{Na}-\mathrm{Ca}-\mathrm{SO} 4-\mathrm{Cl}$ to chloride + sodium $\mathrm{Na}-\mathrm{Cl}$ (Fig. 4). In the anion diagram, the points are grouped on the $\mathrm{Cl}$ chloride pole. In the cation diagram, most of the points are in the Na-K border with a remarkable tendency towards the sodium pole. 


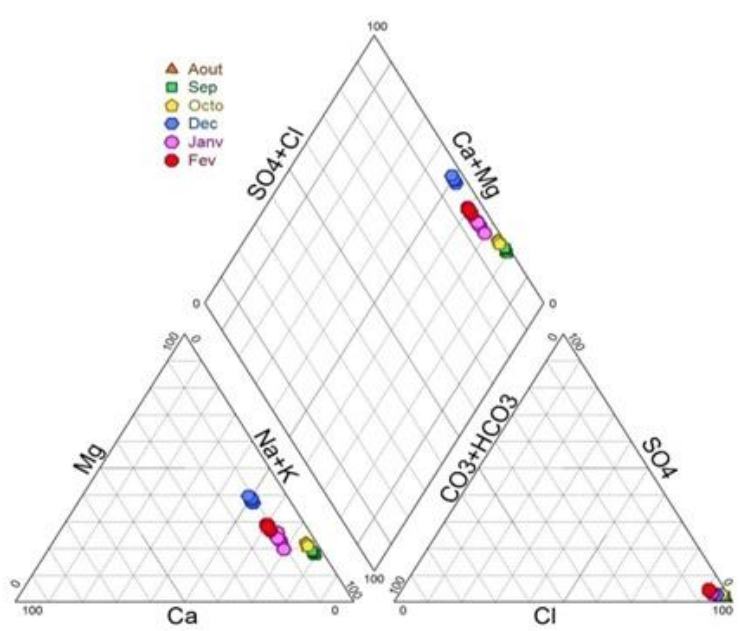

Fig. 4. Hydrochemical facies of Lake water

Table 1. Correlation matrix

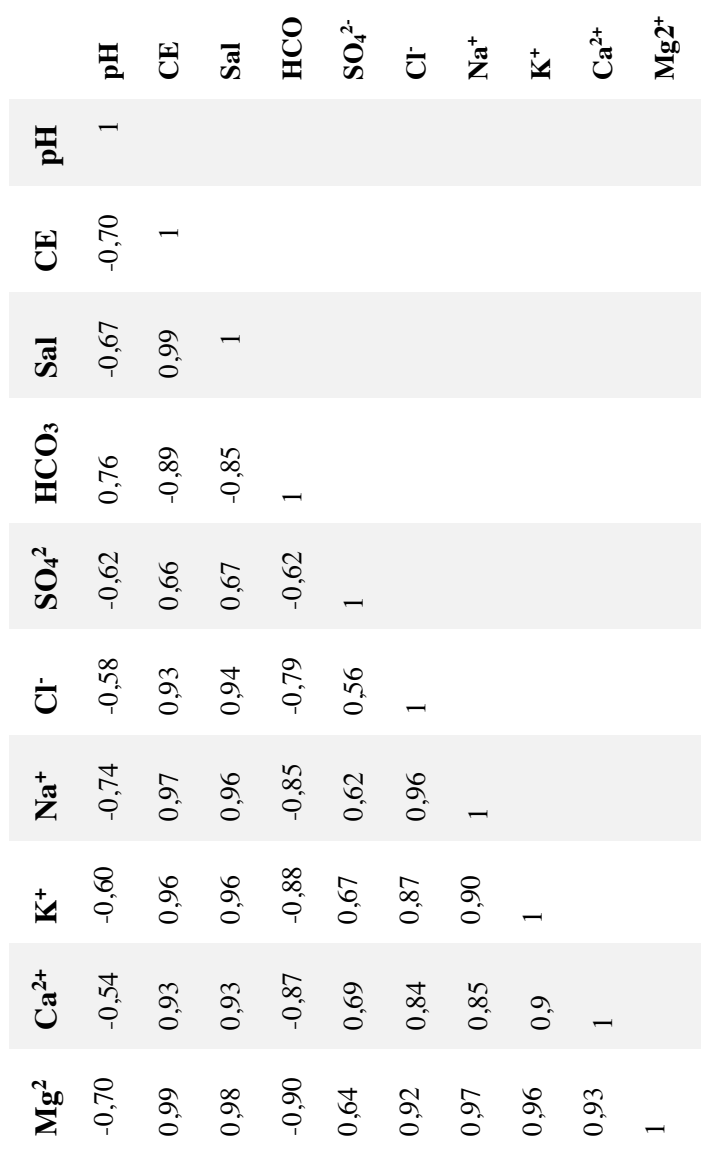

The evolution of $\mathrm{Na}^{+}$is studied as a function of the chloride contents, since the latter is considered as a stable and conservative tracer of evaporites, very soluble, rarely entering saline precipitation and not involved in the oxidation-reduction phenomena [7], [27] and little influenced by the intervention of bacteria. In addition his displacement is not delayed in the water. The $\mathrm{Na} / \mathrm{Cl}$ ratio can be a good tracer for distinguishing marine origin, indeed, in the case of seawater intrusion with $\mathrm{Na} / \mathrm{Cl}<0.86$ and of non-marine or anthropogenic sources $(\mathrm{Na} / \mathrm{Cl} \geq 1)$ [28], [29].

The graphical representation of the evolution of sodium levels as a function of chloride concentrations on a log scale "Fig. 5a", shows that there is a stoichiometric distribution of $\mathrm{Na}$ ions with $\mathrm{Cl}^{-}$ions, indicating the sodium chloride origin common of these two elements.
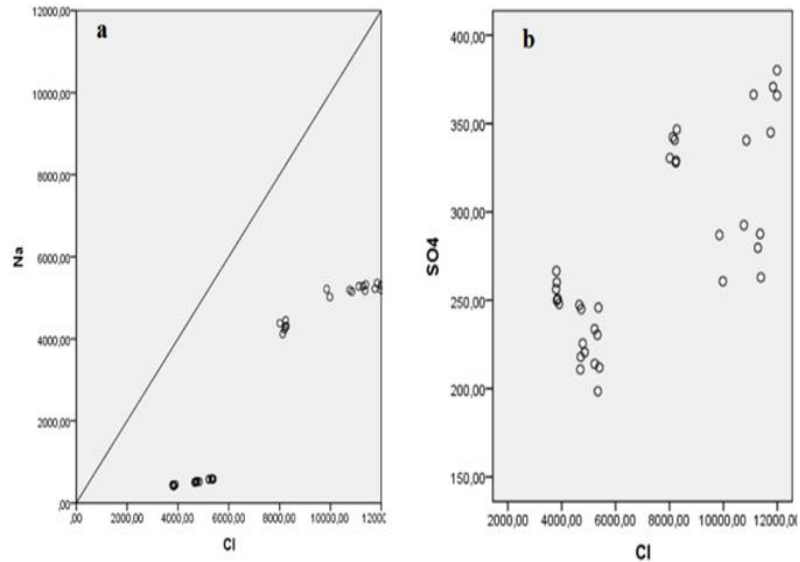

Fig. 5. Variation of Sodium (a) and sulphates (b) in chlorides

The waters of Lac Sidi Boughaba have an ionic ratio $\mathrm{Na} / \mathrm{Cl}<0.5$, what shows the origin of these elements are mainly due to the dissolution of marine salts from aerosols and sea spray (residues of evaporated seawater). This is justified by a complementary study, based on the $\mathrm{SO}_{4}{ }^{2-}$ $/ \mathrm{Cl}^{-}$ratio (Fig. 5b), which decreases when the proportion of seawater in the mixture increases, represented by the content of Cl- [22], [30], [31]. However, lake waters show salt enrichments with low $\mathrm{SO}_{4}{ }^{2-} / \mathrm{Cl}^{-}$values that are less than 0.1 (the seawater cut-off). In addition, groundwater from the Maamora aquifer has low salt content [14], [32] which are considered to be negligible when compared with those in Lake waters.

On the other hand, monitoring the evolution of magnesium as a function of calcium (Fig. 6) shows that the majority of the samples are above the line of slope 1 and thus indicates that calcium and magnesium have an origin different.

Generally, the ratio $\mathrm{Mg}^{2+} / \mathrm{Ca}^{2+}$ increases as a function of the proportion of seawater introduced into the mixture [31], [33], thus the waters of the lake have an $\mathrm{Mg}^{2+} / \mathrm{Ca}^{2+}$ ratio varying from 1 to 4,32 , the minimum value was recorded in the coldest period and the maximum value during the summering period, these values remain different from that of sea water which is of the order of 4,5 .

The magnesium composition for cations can be explained by cationic exchanges between water and the well-developed clay complex in plio-quaternary deposits. This process usually occurs when clays rich in $\mathrm{Mg}$ are in contact with waters rich in $\mathrm{Ca}^{2+}$ or $\mathrm{Na}^{+}$[34].

The origin of these major elements was also discussed using the $\mathrm{Ca}^{2+}, \mathrm{Mg}^{2+}$ and $\mathrm{SO}_{4}{ }^{2-}+\mathrm{HCO}_{3}{ }^{-}$diagram.

If the analytical points are aligned around the line of slope 1 , the dominant reactions are due to the dissolution of calcite, dolomite and gypsum. Base exchange tends to shift points down due to excess $\mathrm{Ca}^{2+}$ and $\mathrm{Mg}^{2+}$ or up due 
to excess $\mathrm{SO}_{4}{ }^{2-}+\mathrm{HCO}_{3}{ }^{-}$[35]. is according to the reaction (1).

$$
2 \mathrm{Na}+\mathrm{Ca}(\mathrm{Mg}) \text { argile } \longrightarrow \mathrm{Na} \text {-Argile }+\mathrm{Ca}^{2+}\left(\mathrm{Mg}^{2+}\right) \text { (1) }
$$

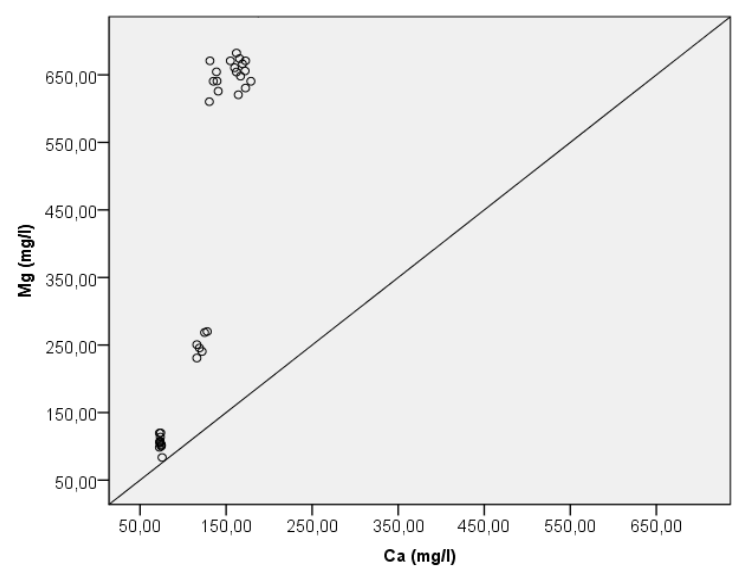

Fig. 6. Evolution of Magnesium in function of calciums

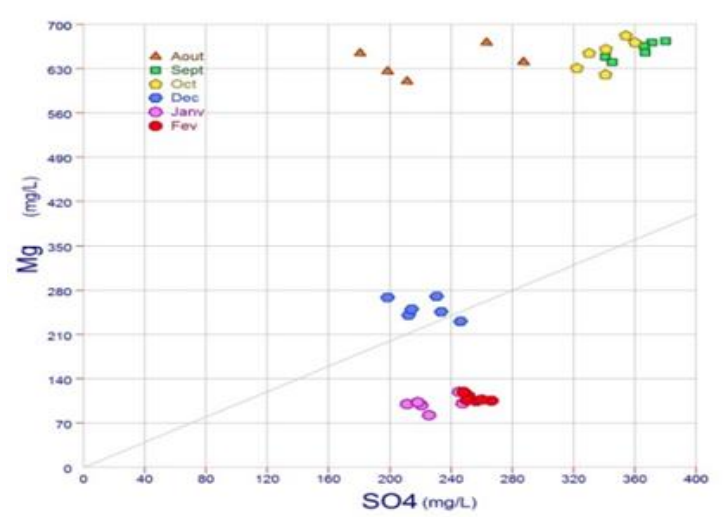

Fig. 7. Evolution of magnesium according to sulfates

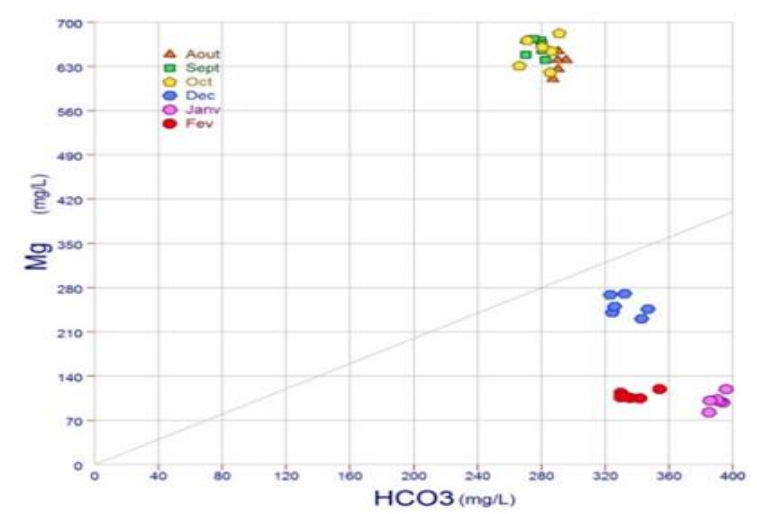

Fig. 8. Evolution of magnesium according to carbonate

Relations of correlations $\left(\mathrm{Ca}^{2+} \mathrm{vS} \mathrm{SO}_{4}{ }^{2-} ; \mathrm{Mg}^{2+} \mathrm{vS} \mathrm{SO}_{4}{ }^{2-}\right)$ show that the points are aligned with the opposite side of the slope, which is indicative of an excess of $\mathrm{Ca} 2+$ and $\mathrm{Mg}^{2+}$ compared to $\mathrm{SO}_{4}{ }^{2-}$.

Generally, sulfate ions can have several origins such as contamination by sulfates of agricultural origin contained in the chemical fertilizers widely used in such agricultural areas and / or the mentioned basic exchanges, which contribute to the decrease $\mathrm{Ca}^{2+}$ contents compared to $\mathrm{SO}_{4}{ }^{2-}$.

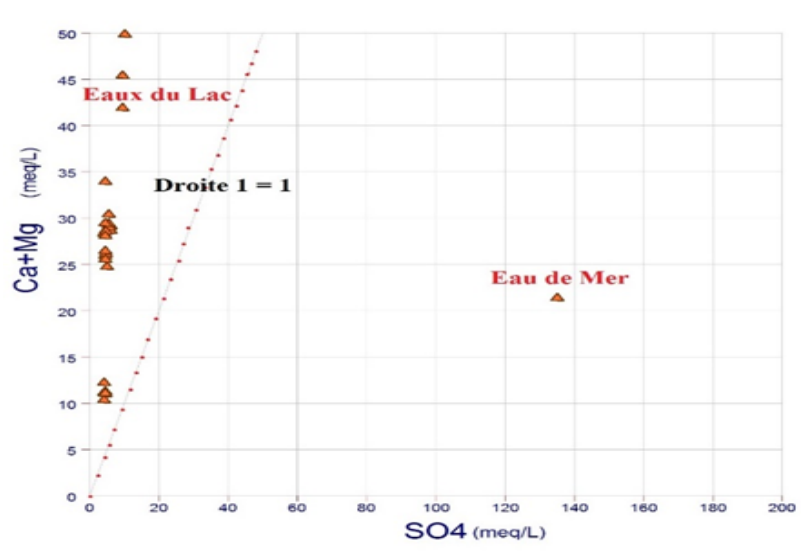

Fig. 9. Relationships $\left(\mathrm{Ca}^{2+}+\mathrm{Mg}^{2+}\right) \mathrm{Vs} \mathrm{SO}_{4}{ }^{2-}$

The water content in $\mathrm{HCO}^{3-}$ shows low values which vary between 2 and $12 \mathrm{meq} / 1$. Generally, the highest contents of $\mathrm{HCO}^{3-}$ characterizes the water taken during the summer season (Fig. 10), relative enrichment in $\mathrm{Ca}^{2+}$ and $\mathrm{Mg}^{2+}$ and the deficit in $\mathrm{HCO}_{3}{ }^{-}$indicates that these elements are not derived from the same origin (dissolution of carbonates).

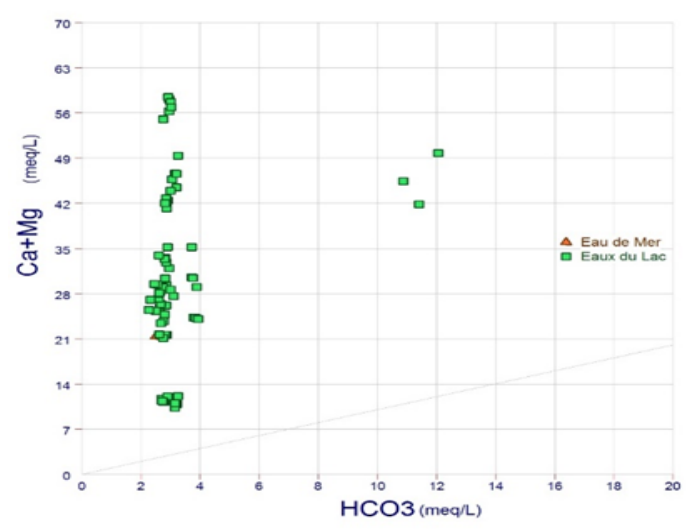

Fig. 10. Relationships $\left(\mathrm{Ca}^{2+}+\mathrm{Mg}^{2+}\right) \mathrm{Vs} \mathrm{HCO}_{3}$

Indeed, the not very significant correlation $(\mathrm{R} 2=0.07)$ of the contents of water $\left(\mathrm{Ca}^{2+}+\mathrm{Mg}^{2+}\right)$ according to the concentrations of $\mathrm{HCO} 3$ - indicates a weak implication of carbonated minerals such as Calcite $\left(\mathrm{CaCO}_{3}\right)$ and the Dolomite $\left(\mathrm{Ca} \mathrm{Mg}\left(\mathrm{CO}_{3}\right)_{2}\right)$ in the mineralization of water. On the graph $\left(\mathrm{Ca}^{2+}+\mathrm{Mg}^{2+} / \mathrm{HCO}_{3}^{-}\right)$(Fig. 10) the points are located largely on the left of the right-hand side of slope 1, indicating an excess of $\mathrm{Ca}^{2+}$ and $\mathrm{Mg}^{2+}$ ions. This site translates the predominance of the mineralization of evaporitic origin.

\section{Conclusion}

The waters of Lac Sidi Boughaba show significant variations in mineralization. The electrical conductivity is generally very high and oscillates between 10440 and $26900 \mu \mathrm{S} / \mathrm{cm}$. The salinity of the water is mainly controlled by chlorides and sodium. The hydrochemical study has revealed the existence of a type of water $\mathrm{Na}-\mathrm{Cl}$ 
sodium chloride facies, they are generally brackish to salty water with a very degradable quality (exceeds the limit of potability of WHO), according to the quality grid, the waters of Lake Sidi Boughaba, were classified among waters of average quality for certain parameters and moved for another. The processes of dissolution / precipitation of water with respect to carbonate minerals (calcite and dolomite) and evaporitic minerals (halite and gypsum) would contribute to the salinization of lake water but in a very weak way. The crossed diagrams of the concentrations of the major elements with the chlorine ion on the one hand, and those of the major elements between them, reveals that the dominance of the chloride and sodium ions in relation to the other elements. The analysis of the ionic ratios $\mathrm{Mg} / \mathrm{Ca}, \mathrm{Cl} / \mathrm{HCO} 3, \mathrm{SO} 4 / \mathrm{Cl}$ and $\mathrm{Na} / \mathrm{Cl}$ shows that these ratios are higher than those of the seawater, which suggests to us a contamination of Lake Waters by salinization. This contamination is explained mainly by the influence of aerosols and sea spray

Acknowledgment. We sincerely thank all members of the laboratory of agrophysiology, biotechnology, environment and quality for their help and cooperation.

\section{References}

1. W. Kloppmann, A. Bourhane, et S. Schomburgk, « Salinisation des masses d'eaux en France métropolitaine et dans l'Outre-mer », Rapport BRGM/RP-59496-FR, 2010.

2. P. Pulido-Leboeuf, « Seawater intrusion and associated processes in a small coastal complex aquifer (Castell de Ferro, Spain) », Appl. Geochem., vol. $19, \mathrm{n}^{\mathrm{o}} 10$, p. 1517-1527, oct. 2004, doi: 10.1016/j.apgeochem.2004.02.004.

3. E. Carol, E. Kruse, et J. Mas-Pla, « Hydrochemical and isotopical evidence of ground water salinization processes on the coastal plain of Samborombón Bay, Argentina », J. Hydrol., vol. 365, n 3, p. 335-345, févr. 2009, doi: 10.1016/j.jhydrol.2008.11.041.

4. S. Krimissa, J.-L. Michelot, L. Bouchaou, J. Mudry, et Y. Hsissou, "Sur l'origine par altération du substratum schisteux de la minéralisation chlorurée des eaux d'une nappe côtière sous climat semi-aride (Chtouka-Massa, Maroc) », Comptes Rendus Geosci., vol. 336, $\mathrm{n}^{\mathrm{o}} 15$, p. 1363-1369, nov. 2004, doi: 10.1016/j.crte.2004.08.003.

5. M. Boughriba, A. Melloul, Y. Zarhloule, et A. Ouardi, «Extension spatiale de la salinisation des ressources en eau et modèle conceptuel des sources salées dans la plaine des Triffa (Maroc nordoriental) », Comptes Rendus Geosci., vol. 338, n 11, p. 768-774, sept. 2006, doi: 10.1016/j.crte.2006.07.007.

6. W. Kloppmann, A. Bourhane, et F. Asfirane, «Méthodologie de diagnostic de l'origine de la salinité des masses d'eau. », Empl. Outils Géochimiques Isot. Geéophysiques BRGM, 2011.
7. Y. Hsissou, J. Mudry, J. Mania, L. Bouchaou, et P. Chauve, «Dynamique et salinité de la nappe côtière d'Agadir (Maroc), influence du biseau salé et des faciès évaporitiques », IAHS Publ.-Ser. Proc. Rep.Intern Assoc Hydrol. Sci., vol. 244, p. 73-82, 1997.

8. Y. Hsissou, J. Mudry, J. Mania, L. Bouchaou, et P. Chauve, «Utilisation du rapport $\mathrm{Br} / \mathrm{Cl}$ pour déterminer l'origine de la salinité des eaux souterraines: exemple de la plaine du Souss (Maroc) », Comptes Rendus Académie Sci.-Ser. IIAEarth Planet. Sci., vol. 328, nº 6, p. 381-386, 1999.

9. S. Najib, « Etude de l'évolution de la salinisation de l'aquifère de la Chaouia côtière (Azemmour-Bir Jdid, Maroc): climatologie, hydrogéologie, hydrochimie et tomographie électrique », Université Chouaib Doukkali, 2014.

10. S. Najib, A. Fadili, K. Mehdi, J. Riss, et A. Makan, « Contribution of hydrochemical and geoelectrical approaches to investigate salinization process and seawater intrusion in the coastal aquifers of Chaouia, Morocco », J. Contam. Hydrol., vol. 198, p. 24-36, mars 2017, doi: 10.1016/j.jconhyd .2017.01.003.

11. Z. Oulaaross, «Etude climatologique, hydrogéologique et géophysique du Sahel Côtier des Doukkala (Maroc). Apport de l'analyse statistique et de l'inversion des données géoélectriques à l'étude du biseau salé de la lagune de Sidi Moussa », $\mathrm{PhD}$ Thesis, Bordeaux 1, 2009.

12. L. Zouhri, « L'aquifere du bassin de la Mamora, Maroc: geometrie et ecoulements souterrains », $J$. Afr. Earth Sci., vol. 4, n 32, p. 837-850, 2001.

13. L. Zouhri, C. Lamouroux, D. Vachard, et A. Piqué, « Les corps perméables plio-quaternaires de la Mamora (Maroc). Géométrie et influence structurale », Comptes Rendus Académie Sci.-Ser. IIA-Earth Planet. Sci., vol. 332, nº 1, p. 1-4, 2001.

14. L.Zouhri, E. Arbi Toto, E. Carlier, et T.-H. Debieche, «Salinité des ressources en eau: intrusion marine et interaction eaux-roches (Maroc occidental) », Hydrol.Sci. Journal-Journal Sci. Hydrol., vol. 55, $\mathrm{n}^{\circ}$ 8, p. 1337-1347, 2010.

15. M. Ramdani, « Recherches hydrobiologiques sur la merja Sidi Boughaba (littoral atlantique du Maroc): étude physico-chimique et analyse faunistique », Bull Inst Sci Rabat, vol. 5, p. 37-137, 1981.

16. M. Thévenot, «Les oiseaux de la réserve de SidiBou-Rhaba », Bull Inst Sci Rabat, vol. 1, p. 68-90, 1976.

17. R. Trabelsi, M. Zaïri, H. Smida, et H. B. Dhia, «Salinisation des nappes côtières: cas de la nappe nord du Sahel de Sfax, Tunisie », Comptes Rendus Geosci., vol. 337, $\mathrm{n}^{\circ}$ 5, p. 515-524, 2005.

18. G. JACQUMEIN, « Les Odonates de la Merja de Sidi Bou Ghaba (Mehdiya, Maroc). », Bull Inst Sci, $\mathrm{n}^{\circ} 11$, p. 175-183, 1987.

19. M. Najy et al., « Assessment of the Water Quality of Lake Sidi Boughaba (Ramsar Site 1980) Kenitra, 
Morocco. », Invent. J. Res. Technol. Eng. Manag. IJRTEM, vol. 2, $\mathrm{n}^{\circ}$ 5, p. 52-60, mai 2018.

20. ABHS., "Agence du bassin hydraulique de Sebou Fès. Présentation des bassins hydrauliques du Maroc », 2013.

21. D. L. Parkhurst et C. A. J. Appelo, « Description of input and examples for PHREEQC version 3: a computer program for speciation, batch-reaction, one-dimensional transport, and inverse geochemical calculations », US Geological Survey, 2013.

22. P.Pulido-Leboeuf, A. Pulido-Bosch, M. L. Calvache, Á. Vallejos, et J. M. Andreu, «Strontium, SO 42 -

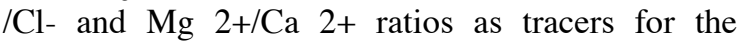
evolution of seawater into coastal aquifers: the example of Castell de Ferro aquifer (SE Spain) », Comptes Rendus Geosci., vol. 335, n 14 , p. 10391048, 2003.

23. N. C. Mondal, V. P. Singh, V. S. Singh, et V. K. Saxena, « Determining the interaction between groundwater and saline water through groundwater major ions chemistry », J. Hydrol., vol. $388, \mathrm{n}^{\circ} 1$, p. 100-111, 2010.

24. H. Arslan, « Application of multivariate statistical techniques in the assessment of groundwater quality in seawater intrusion area in Bafra Plain, Turkey », Environ. Monit. Assess., vol. 185, n 3, p. 2439-2452, 2013.

25. B. Askri, A. T. Ahmed, R. A. Al-Shanfari, R. Bouhlila, et K. B. K. Al-Farisi, " Isotopic and geochemical identifications of groundwater salinisation processes in Salalah coastal plain, Sultanate of Oman », Chem. Erde - Geochem., vol. $76, \mathrm{n}^{\mathrm{o}} 2$, p. 243-255, juin 2016, doi: 10.1016/j.chemer.2015.12.002.

26. R. Ledesma-Ruiz et J. Mahlknecht, « Geochemical and Isotopic Characterization of Groundwater in Tecate, Baja California, Mexico », 15th Water-Rock Interact. Int. Symp. WRI-15, vol. 17, p. 516-519, janv. 2017, doi: 10.1016/j.proeps.2016.12.130.

27. Y. Hsissou, «Impact de l'environnement naturel et anthropique sur la qualité des eaux alluviales en zone semi-aride-cas de la plaine du Souss (Maroc) », Theese Dr. D'état Univ Ibn Zohr Agadir, p. 228, 1999.

28. I. Gavrieli, Y. Yechieli, L. Halicz, B. Spiro, A. Bein, et D. Efron, « The sulfur system in anoxic subsurface brines and its implication in brine evolutionary pathways: the Ca-chloride brines in the Dead Sea area », Earth Planet. Sci. Lett., vol. 186, no 2, p. 199-213, mars 2001, doi: 10.1016/S0012$821 \mathrm{X}(01) 00247-3$.

29. A. Vengosh, « Salinization and saline environments », Treatise Geochem., vol. 9, p. 612, 2003.

30. A. Vengosh et E. Rosenthal, « Saline groundwater in Israel: its bearing on the water crisis in the country », J. Hydrol., vol. 156, n 1-4, p. 389-430, 1994.
31. R. Trabelsi, M. Zaïri, H. Smida, et H. B. Dhia, «Salinisation des nappes côtières: cas de la nappe nord du Sahel de Sfax, Tunisie », Comptes Rendus Geosci., vol. 337, nº 5, p. 515-524, 2005.

32. I. Kherrati et al., " Health Risk of Maâmora's Groundwater Pollution in Morocco », Nat. Resour., vol. 6, nº 04, p. 290, 2015.

33. J. H. Tellam, « Hydrochemistry of the saline groundwaters of the lower Mersey Basin PermoTriassic sandstone aquifer, UK », J. Hydrol., vol. $165, n^{\circ} 1-4$, p. 45-84, 1995.

34. C. A. J. Appelo et D. Postma, Geochemistry, groundwater and pollution. CRC press, 2004.

35. A. Khedidja et A. Boudoukha, « statistical and hydrochimical characterization of the shallow aquifer of tadjnanet-chelghoum LAID (EASTERN ALGERIA) », LARHYSS J. ISSN 1112-3680, n 28, p. 181-197, 2016. 